\title{
スリットから吸込みを伴う管内乱流に関する研究*
}

\author{
深 澤 薰*1, 佐 野 正 利*2

\section{Study on Turbulent Channel Flow with Suction through a Slit} \\ Kaoru FUKASAWA and Masatoshi SANO*3 \\ ${ }^{* 3}$ Department of Mechanical Engineering, Chiba Institute of Technology, \\ 2-17-1 Tsudanuma, Narashino-shi, Chiba, 275-0016 Japan

\begin{abstract}
Experiments have been performed on turbulent channel flow with suction through a slit. The inclined angle of the suction is changed $30^{\circ}, 60^{\circ}$ and $90^{\circ}$ at the main stream velocity $10 \mathrm{~m} / \mathrm{s}$. The dimensionless suction flow ratio is varied nine steps in the range of $0.067 \sim 0.500$. In order to investigate the relationship between fluid flow and heat transfer characteristics, local heat transfer coefficient, wall static pressure, wall shear stress, velocity profile and turbulence intensity are measured. In addition, the velocity profiles of the suction region are measured by the particle image velocimetry (PIV). Difference due to the inclined angle is not observed in the result of wall pressure and heat transfer coefficient. The heat transfer coefficient decreases as the suction flow ratio increases. The recovery mechanism of turbulence is greatly different between the lower side and upper side of the channel.
\end{abstract}

Key Words: Turbulence, Channel Flow, Suction, Heat Transfer, Pressure Drop, PIV, Wall Shear Stress, Velocity Profile, Turbulence Intensity

\section{1. 緒論}

乱流を制御するための方法として, 壁面からの吸込 みや吹出しが有効であることが知られている．特に, 吸込みを用いることにより, 壁面近傍の運動量の小さ な流体を吸い込むことではく離を防止することや，境 界層の遷移を遅らせ, 摩擦抵抗を低減させることが可 能である.また, 乱流境界層に対して吸込みを行った 場合には, 壁面付近の乱れが抑制されることにより再 層流化現象が起こることも知られている(1).ここで, 壁面から吸込みを行う方法としては, 壁面を多孔質と して一様に吸込みを行う方法と円孔やスリットから局 所的に吸込みを行う方法とに大別される. 一様吸込み に関してはこれまで理論的, 実験的に多くの研究がな されてきた(2)(3). 一方, 円孔やスリットからの吸込み は流れの制御を行うにあたり局所的な操作が可能であ り，また壁面を多孔質とする必要がないために加工面, コスト面においてもより実用的であると考えられる. 局所吸込みに関するこれまでの研究例として, 佐野

* 原稿受付 2005 年 7 月 19 日.

*1 正員, 千葉工業大学大学院工学研究科(-275-0016 習志野 市津田沼 2-17-1)

*2 正員, 千葉工業大学工学部.

E-mail : sano.masatoshi@it-chiba.ac.jp
ら (4) は乱流境界層に対してスリットから吸込みを行 い，吸込みにより非平衡となった流れが，どのような 過程を経て平衡な状態へと回復していくかを流動特性 の測定から明らかにし, Antonia ら(1), Oyewola ら(5) は平板上に設置した多孔質ストリップから吸込みを行 った場合の乱流構造の変化について調査している。ま た，小森ら ${ }^{(6)}$ は局所吸込みを伴う層流境界層の流動特 性と伝熱特性について調查し，吸込み直後で熱伝達率 が吸込みのない場合と比較して増加することを報告し ている，しかしながら，これらの研究では境界層を解 析対象としており，管内乱流における研究は数少ない のが現状である．管内乱流に対して吸込みを行った研 究例として, 例えば Sofialidis ら ${ }^{(7)}$ は十分発達した円 管内乱流について数種類の乱流モデルを用いて数值計 算を行い, 実験結果との比較から各乱流モデルの数值 予測精度を検証している，また，これまでの吸込みの ある管内乱流に関する研究では, 流動特性の解析に重 点がおかれ伝熱特性まで含めて解析を行った例はあま り存在しない.

そこで, 本研究では二次元的なスリットから吸込み を伴うチャネル内乱流を解析対象として取り上げ, 吸 込み角度, 吸込み流量比を種々に変化させた条件のも とで, 熱伝達率, 壁面静圧, 損失係数, 壁面せん断応 
力, 速度分布, 乱流強度分布などの測定を行うことに より，スリットからの吸込みがチャネル乱流の伝熱特 性や流動特性に及ほす影響を実験的に明らかにする。

\section{2. 実験装置および実験方法}

本研究で使用した実験装置の概要を図 1 に, 吸込み 部の詳細と座標系を図 2 に示す. 実験には主流用と吸 込み用の 2 台の送風機を使用する. 厚さ $10 \mathrm{~mm}$ のア クリル板で製作された試験流路は，高さ $H$ が $30 \mathrm{~mm}$, 幅が $250 \mathrm{~mm}$ の長方形断面となっている．流路入口 の上下壁面には, 早期に発達した乱流を得るために直 径 $15 \mathrm{~mm}$ のトリッピングワイヤが設置されている. スリット部に至るまでの助走区間の長さは $1500 \mathrm{~mm}$, スリットより下流方向への長さは $1540 \mathrm{~mm}$ である. 実験は主流の断面平均速度 $U_{\mathrm{in}}$ を $10 \mathrm{~m} / \mathrm{s}$ の一定とし て行った。スリットから吸い込まれる流体は吸込み用 流路を通過した後, 大気へと放出される。吸込み用流 路の途中にはオリフィス流量計が設置してあり, 所定 の吸込み流量に設定される。なお，吸込み流速度が一 様となるようスリットの下流には金属を焼結した多孔 板が取付けられている.スリット幅 $L$ は $10 \mathrm{~mm}$ で, 座標系はスリットからの流れ方向距離を $x$, 下側壁面 からの垂直方向距離を $y$ とする. また, $x, y$ 方向の時 間平均速度および変動速度をそれぞれ $U, u$ ならびに $V, v$ とし，スリットからの吸込み速度を $V_{s}$ とする. 吸込み角度 $\alpha$ は, 主流に対して $30,60,90^{\circ}$ の 3 種類 に変化させた。吸込み流量比 $Q$ は次式で定義し,

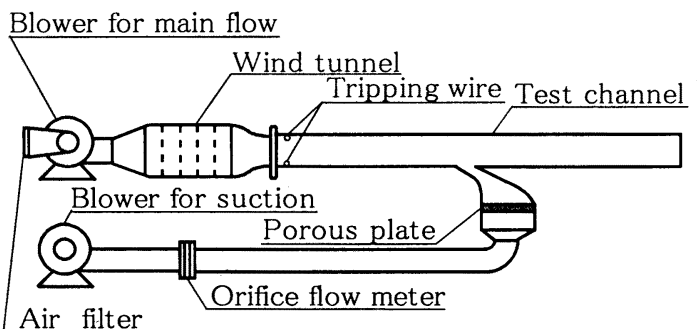

Fig. 1 Experimental apparatus

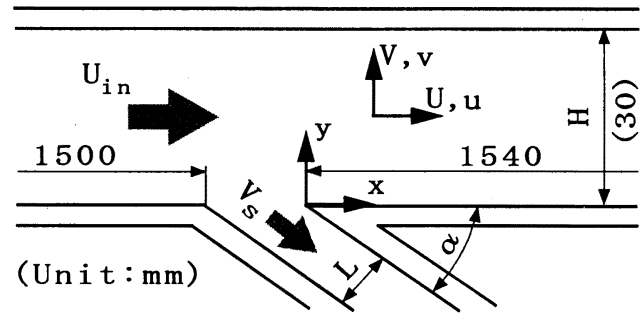

Fig. 2 Coordinate system and definition of symbols

$$
Q=\frac{V_{s} L}{U_{\text {in }} H}
$$

$Q=0.067,0.133,0.200,0.267,0.333,0.400$, $0.433,0.467,0.500$ と 9 種類に変化させて実験を行 った. 本実験条件のもとで壁面静圧, 損失係数, 速度 分布, 乱流強度分布を測定した。壁面静圧は流路のス パン中心に設けられた直径 $0.5 \mathrm{~mm}$ の静圧孔と微差 圧力計(Rosemount 製：N $1151 \mathrm{DR}$ )を用いて測定し, 次式で定義される壁面静圧係数 $C_{p}$ により整理した。

$$
\begin{aligned}
& C_{p}=\frac{p-p_{0}}{\frac{1}{2} \rho U_{\mathrm{ln}}^{2}} \\
& \text { ただし, } \\
& \rho: \text { 空気密度 } \\
& p: \text { 壁面静圧 } \\
& p_{0}: \text { 大気圧 }
\end{aligned}
$$

また，流路中央からスパン方向の左右 $75 \mathrm{~mm}$ 離れた 位置に設置された静圧孔を用いて圧力分布に良好な二 次元性が確保されていることを確認した。損失係数 は, 図 3 に $\alpha=90^{\circ}, Q=0.500$ における流路上壁面の 場合を代表例として示したように,ベルヌーイの式に 基づいて得られる圧力回復と実験的に得られる圧力回 復 $\left(\Delta C_{p}=C_{p_{2}}-C_{p_{1}}\right)$ との差をとることにより求めた. すなわち，らは次式にて定義した(8).

$$
\zeta=\frac{\Delta p_{\text {loss }}}{\frac{1}{2} \rho U_{\mathrm{in}}^{2}}=\left[1-\left(\frac{U_{m}}{U_{\mathrm{in}}}\right)^{2}\right\}-\Delta C_{p}
$$

ただし，

$U_{\text {in }}$ : スリット上流での断面平均速度

$U_{m}:$ スリット下流での断面平均速度

$\Delta p_{\text {loss }}:$ 圧力損失

壁面せん断応力の測定には, マイクロフローセンサ (山武製)を使用した。 マイクロフローセンサは MEMS 技術を用いた熱式センサであり，壁面近傍で の流れの方向 (順流と逆流)および壁面せん断応力の測 定が可能である(9). 速度と乱れの計測には, 定温度形

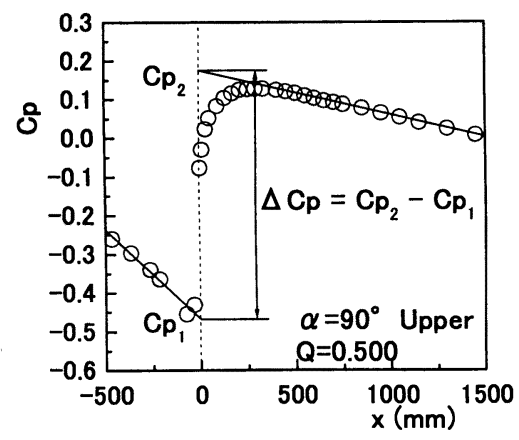

Fig. 3 Evaluation method of loss factor 
熱線流速計と I 形熱線プローブおよび二次元粒子画像 流速計 (PIV) (TSI 社製)を用いた，PIVによる測定 では, 光源に出力 $120 \mathrm{~mJ} /$ Pulse のダブルパルス $\mathrm{Nd}$ ：YAGレーザ(DPIV-N 120)を用い, シリンドリ カルレンズによりシート状にされたレーザ光は測定部 でのシート厚さが約 $0.14 \mathrm{~mm}$ となるように調節し た。画像記録には 8 bitCCD カメラ(解像度 $1008 \times$ 1018 pixel) (MODEL 630046)を用いており, サンプ リング周波数は $15 \mathrm{~Hz}$ である.トレーサ粒子は煙発 生装置(DANTEC：SAFEX Fog Generator 2001)に より生成した. 可視化画像は瞬時画像を 1000 frame 取得し, FFT 相互相関法により流速べクトルを算出 した.

熱伝達率の測定にあたっては， $x=40 \mathrm{~mm}$ より下流 の流路下側の平板を厚さ $20 \mathrm{~mm}$ のベークライト板に 取り替え, この板に厚さ $30 \mu \mathrm{m}$ のステンレスはくを接 着し, 熱流束一定の条件で通電加熱した. 伝熱面温度 は,ステンレスはくの裏側に取付けられた直径 0.1 $\mathrm{mm}$ の $\mathrm{T}$ 形熱電対により求めた.また, ベークライ ト板の裏側にも熱電対を取付け, 伝熱面裏側からの熱 損失の評価に用いた。主流温度は流路入口から 100 $\mathrm{mm}$ 下流の流路中央位置にある $\mathrm{T}$ 形熱電対により測 定した. 局所熱伝達率 $h_{x}$ は次式にて定義した。

$$
h_{x}=\frac{q}{T_{w}-T_{m}}
$$

ここで, $T_{w}$ は局所伝熱面温度, $T_{m}$ は $T_{w}$ を測定した 位置における混合平均温度, $q$ は熱損失補正後の熱流 束である. また, 局所ヌッセルト数 $N u$ は次式にて定 義した。

$$
\begin{aligned}
& N u=\frac{h_{x} \cdot d_{e}}{k} \cdots . . . . . . . \\
& \text { ただし } \\
& d_{e}: \text { 水力直径 } \\
& k: \text { 空気の熱伝導率 }
\end{aligned}
$$

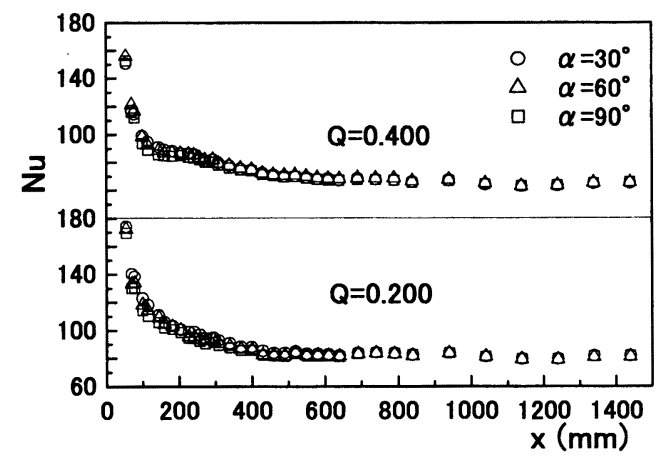

Fig. 4 Distributions of local Nusselt number

\section{3. 実験結果および考察}

$3 \cdot 1$ 吸込み角度の影響 図 4 に吸込み角度 $\alpha$ の 相違が局所ヌッセルト数 $N u$ に及ほす影響を調査し た結果を吸込み流量比 $Q=0.200,0.400$ の場合を代表 例として示す.いずれの $Q$ においても $N u$ 数はスリ ット近傍で高く，下流に進むにしたがって緩やかに減 少し， $x=800 \mathrm{~mm}$ より下流ではほほ一定值となる. 図 4 からはあまり明りょうではないが，スリット近傍 にわずかな相違があるものの $N u$ 数分布には $\alpha$ の影 響はほとんど認められない.この傾向は他の吸込み流 量比においても同様であった。

図 5 に流路下壁面の静圧係数 $C_{p}$ の流れ方向変化を $\alpha$ により比較した結果を示す.ここでも $N u$ 数と同様 に $Q=0.200,0.400$ の場合について示している.いず れの条件においてもスリット上流の $C_{p}$ はほほ同一の 傾きで直線的に減少しており，スリットに至る流れが 発達した流れとなっていることが確認できる， $C_{p}$ の 測定結果においてもすべての $\alpha$ において分布形状は ほぼ同一となっていることがわかる.

図 6 は流路下壁面の静圧係数より求めた損失係数 $\zeta$ を流量比 $Q$ に対してプロットした結果を示している. いずれの $\alpha$ においても $Q=0.067 \sim 0.267$ の範囲にお いて，損失係数は負の值を示している。これは，吸込

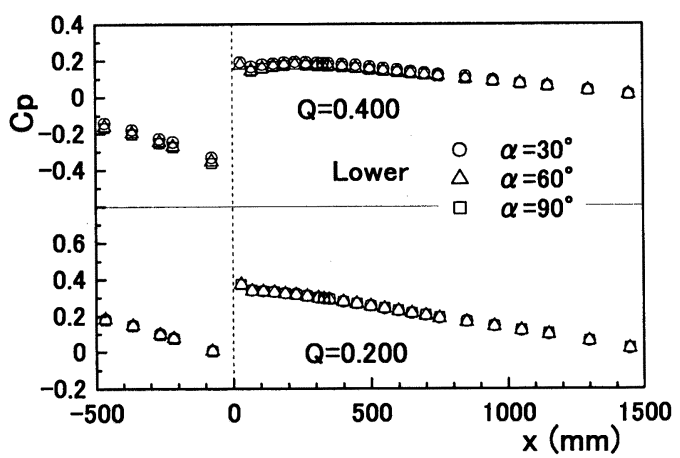

Fig. 5 Distributions of wall static pressure coefficient

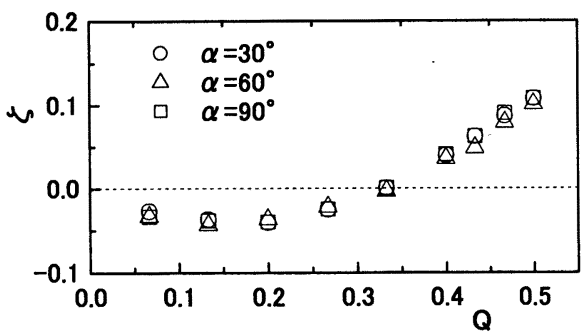

Fig. 6 Pressure loss against suction flow ratio 


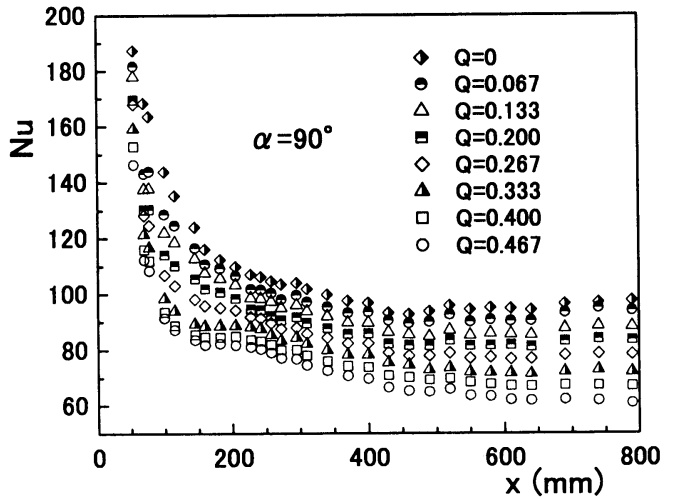

(a)

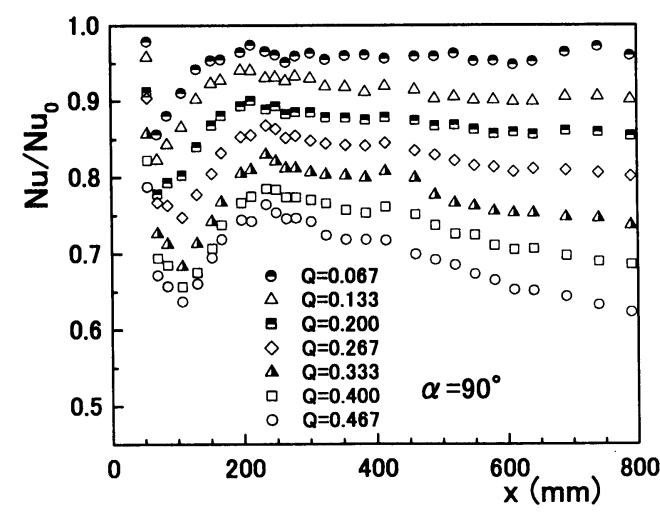

(b)

Fig. 7 Distributions of local Nusselt number

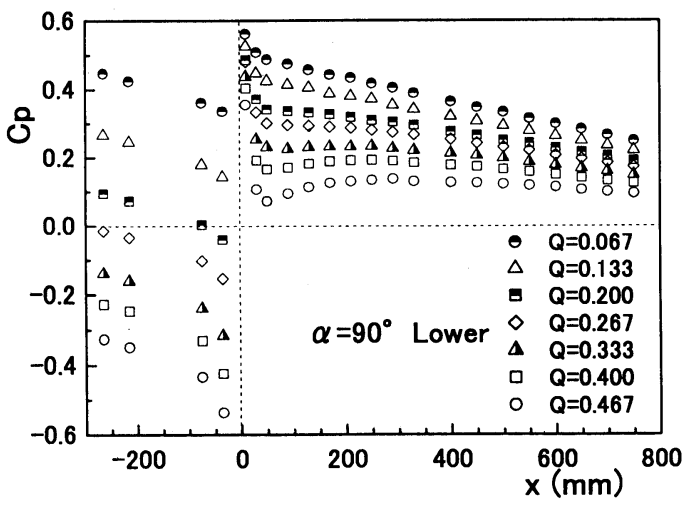

(a)

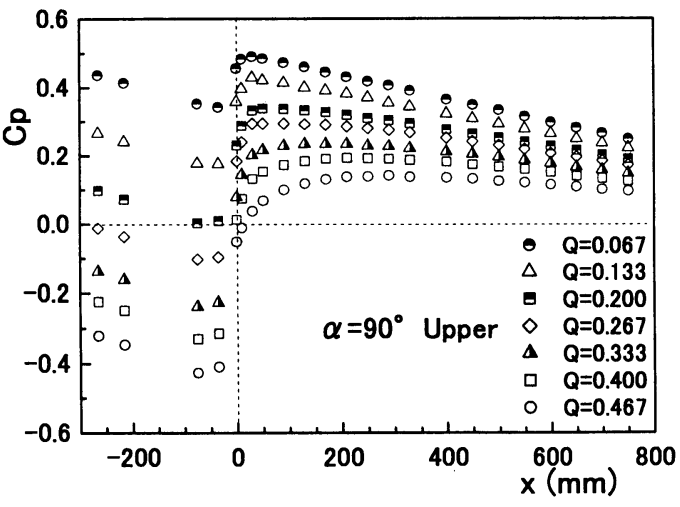

(b)

Fig. 8 Distributions of wall static pressure coefficient

み流量比が小さい場合には吸込みによりスリット近傍 の流体が流れやすくなっているためと考えられる．な お，このような傾向は T 形分岐管における本流の損 失係数にも見られるものである(8). また, 図 5 に示し た結果からも予想されるように損失係数においても $\alpha$ による相違はほとんど観察されない. 以上の結果よ り，吸込み角度の相違が熱伝達率ならびに壁面静圧に 与える影響は極めて小さいことがわかる．したがっ て, $3 \cdot 2$ 節以降の吸込み流量比の影響を調査した結果 においては， $\alpha=90^{\circ}$ の場合を代表例として示すこと とする.

\section{$3 \cdot 2$ 吸込み流量比の影響}

$3 \cdot 2 \cdot 1$ 局所ヌッセルト数分布 図7(a)にNu 数の流れ方向変化を，(b)にはスリットをテープにて ふさいだ条件のもとで測定された吸込みを行っていな い場合 $(Q=0)$ における局所ヌッセルト数 $N u_{0}$ を用い て整理した結果を $Q$ により比較して示す。なお，図 4 に示した結果より, $x=800 \mathrm{~mm}$ 程度より下流では $N u$
数の流れ方向変化は非常に小さくなったために,ここ では $x=800 \mathrm{~mm}$ までの結果を示している. 図7( a ) より, 吸込みのない場合において加熱開始位置付近で $N u$ 数が非常に大きな値となっているのは前縁効果に よるものであるが，吸込みのある場合においてもこの 傾向に変化はないことがわかる，Qの増加に伴い吸 込みのない場合に比較して $N u$ 数は低下する. しか しながら，この低下は単調でなく，吸込みが強くなる につれて $x=100 \sim 250 \mathrm{~mm}$ 付近における隇少が緩和 され, $Q=0.333$ 以上では $N u$ 数の值が流れ方向にほ とんど変化しない領域が現れる.この下流では $N u$ 数は緩やかに減少し, 一定值へと漸近する.図 7(b) からは,いずれの $Q$ においても，スリット直後から $x=100 \mathrm{~mm}$ 付近までに $N u / N u_{0}$ の分布に極小值が現 れるが, その後増加して, $x=200 \mathrm{~mm}$ 付近に極大值が 現れていることがわかる。これらの結果は, スリット 後方の壁面近傍における流れが吸込みにより大きく変 化することを示している，なお，層流境界層に対して 
吸込みを行った研究では, 吸込み直後において吸込み のない場合よりも局所熱伝達率は増加することが報告 されている(6). しかしながら, チャネル乱流ではその ような現象が発生することはない. 境界層の場合とは 異なりチャネル乱流では, 吸込みにより欠損した流量 が主流側から補完されることがないことが一因と考え られる.

$3 \cdot 2 \cdot 2$ 壁面静圧係数分布四 8(a)に流路下壁 面, (b)に流路上壁面において測定された壁面静圧係 数 $C_{p}$ の流れ方向変化を $Q$ により比較した結果を示 す.図8(a)より, 流路下壁面では $Q$ が大きいほどス リット上流および下流の $C_{p}$ 值が隇少していることが 確認できる.なお， $Q$ の増加につれてスリット下流に おける $C_{p}$ の流れ方向への傾きが小さくなるのは, 吸 込み流量の增加に伴いスリットより下流の断面平均速 度が減少したことによる. スリット近傍に着目する と, スリット直前に最小值が現れ, その後急激な圧力 回復がなされている.この結果は, 急拡大を伴う管内 乱流の圧力分布の傾向とも類似している(10). いずれ の $Q$ においてもスリット直後に最大值が現れ, その 後 $Q$ が小さい場合にはただちに直線的な分布へと移 行するが, $Q$ が大きくなると最大值が現れた後に $x=$ $50 \mathrm{~mm}$ 付近まで $C_{p}$ 值は減少し, 極小值が現れてい る.この傾向は $Q$ が大きいほど顕著となっており, スリット直後で流れの加速が生じていると考えられ る. また, $Q$ が大きい場合には $C_{p}$ は再び増加して極

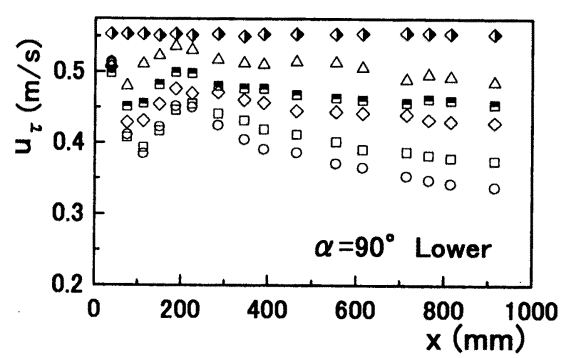

(a)

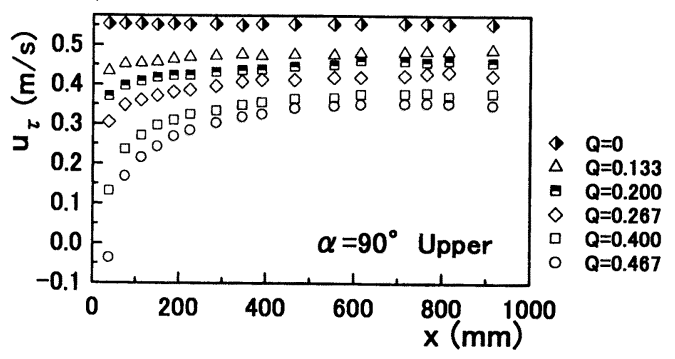

(b)

Fig. 9 Friction velocity
大値が現れるような分布形状となる.図 8(b)に示し た流路上壁面における $C_{p}$ の測定結果では, 下壁面と は異なりスリット直後での $C_{p}$ の急激な隇少は認めら れない.また, $Q=0.467$ ではスリット直後において $C_{p}$ の值が負となっている.この結果は, 強い吸込み を行った場合には, 逆圧力こう配が発生することによ って低速域が流れ方向に拡大し，この領域ではく離が 発生している可能性を示唆するものである.

$3 \cdot 2 \cdot 3$ 摩擦速度 図 9 に $Q$ の相違が摩擦速度 uてに及ほす影響を調查した結果を示す。なお，図 9（a）は下壁面を，(b) は上壁面の測定結果を示して いる. 上壁面, 下壁面ともに $Q$ が大きくなるにつれ て $u_{\tau}$ の值が減少するのは, 吸込みによりスリット後 方での流量が減少するためである. 下壁面の結果で は, 吸込みを行った場合いずれの $Q$ においても $u_{\tau}$ の 分布には $x=100 \mathrm{~mm}$ 付近までに極小值が見られ，そ の後增加して極大值が現れている．その下流では緩や かな減少が認められる.この傾向は, 図 7(b)に示し た $N u / N u_{0}$ の流れ方向変化の結果ともよく一致してお り, 壁面せん断応力の変化が熱伝達率の増減に密接に 関係していることを示している。一方, 上壁面の結果 では, 下壁面の結果とは異なり, 極小值や極大値が現 れることはなく, スリット直後の小さな值から下流方 向に向かって単調に増加している. また, 上壁面では 下壁面に比較して $u_{\tau}$ はよりスリットに近い位置から 一定值に近くなっている.したがって, 上壁面側の流 れは, 下壁面側に比較して平衡な状態に回復しやすい ことを示している. なお， $Q=0.467$ においてはスリ ット直後で $u_{\tau}$ の值が負 $\left(u_{\tau} \fallingdotseq-0.04 \mathrm{~m} / \mathrm{s}\right)$ となって いることから,わずかに逆流が生じており, 壁面静圧 係数の測定で示唆された流れのはく離が壁面せん断応 力の測定から確認されたことになる.

$3 \cdot 2 \cdot 4$ 速度分布 図 10 はPIVにより測定され たスリット近傍の時間平均速度分布を $Q=0.400$ を代

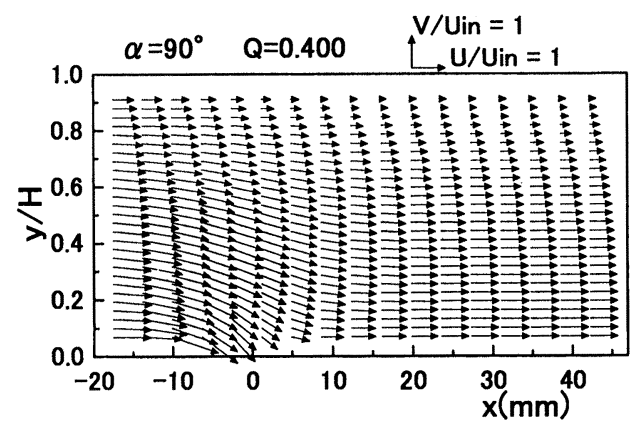

Fig. 10 Velocity vector $(Q=0.400)$ 


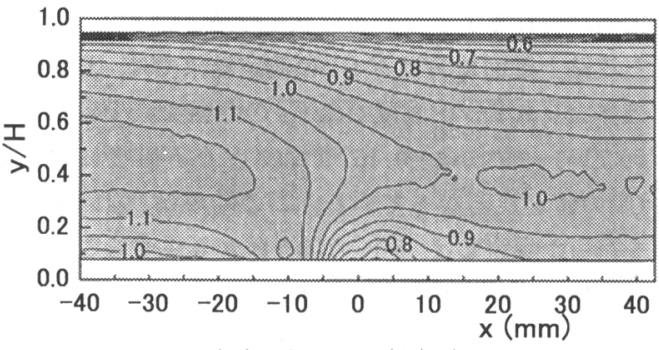

(a) $Q=0.200\left(U / U_{\text {in }}\right)$

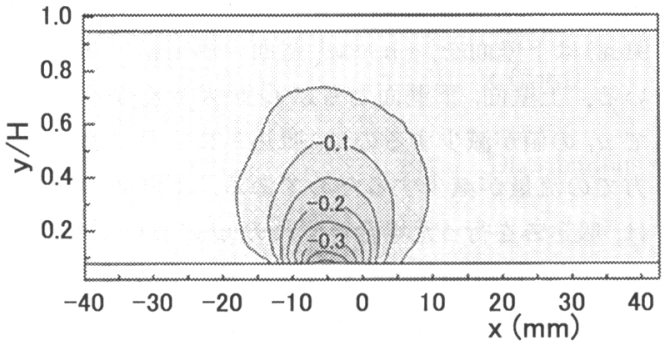

(c) $Q=0.200\left(V / U_{\text {in }}\right.$

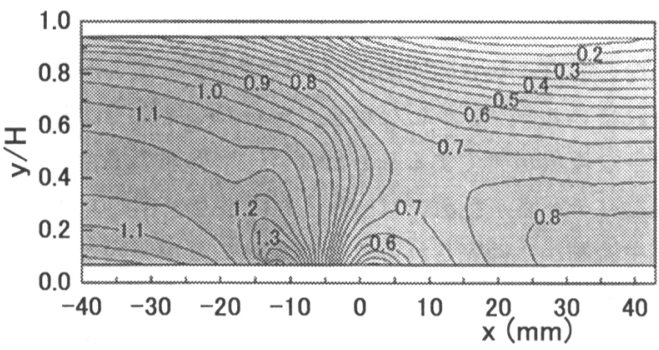

(b) $Q=0.400\left(U / U_{\text {in }}\right)$

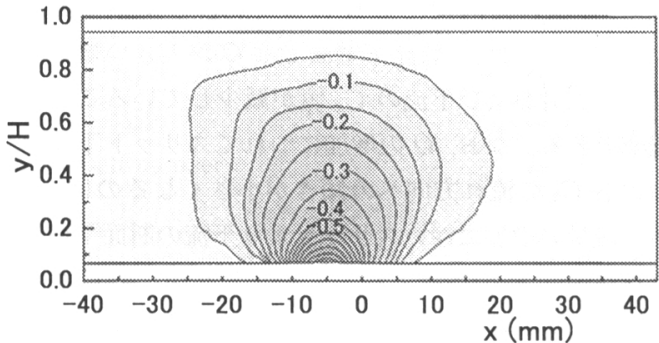

(d) $Q=0.400\left(V / U_{\text {in }}\right)$

Fig. 11 Contours of mean velocity

表例としてベクトルで表示した結果である。流れ方向 時間平均速度 $U$ ならびに垂直方向時間平均速度 $V$ は $U_{\text {in }}$ を用いて無次元化がなされている。ここで, スリ ット部は $x=-10 \sim 0 \mathrm{~mm}$ の範囲にある。スリット付 近には強い下向きの流れが見られる. スリットを通過 した後には, 下向きの流れは早期に壁面とほぼ平行な 流れへと変化し, $x=30 \mathrm{~mm}$ よりも下流では垂直方向 の速度成分は非常に小さくなっていることが確認でき る.

図 11( a ) （d)には $Q=0.200$ と $Q=0.400$ を代 表例として PIVを用いて测定されたスリット近傍に おけるUと $V$ を等值線として示した。図 11(a), (b ) より, 高速な流れがスリット上流の流路中央付近 からスリット部へと向かうようすが確認できる、スリ ット直後の下側壁面近傍には低速領域が現れるが，こ の領域よりも下流では再び流れが加速されているよう すが観察できる.また， $Q=0.400$ のスリット下流で は, 吸込みにより流体が流路下側へと強く引き寄せら れてしまうために, 流路上側の極めて広い範囲におい て低速領域が存在している。図 11( c )，(d) に示した 垂直方向速度成分に関しては，いずれの吸込み比に対 してもスリット部を中心として等值線はほぼ線対称な 扇状の分布となっていること，また吸込流量比の大き い $Q=0.400$ においても $x=20 \mathrm{~mm}$ 付近ですでに $V / U_{\text {in }}$ の值は $5 \%$ 以下となっていることが確認でき る. 吸込みによる垂直方向速度成分はスリット近傍で

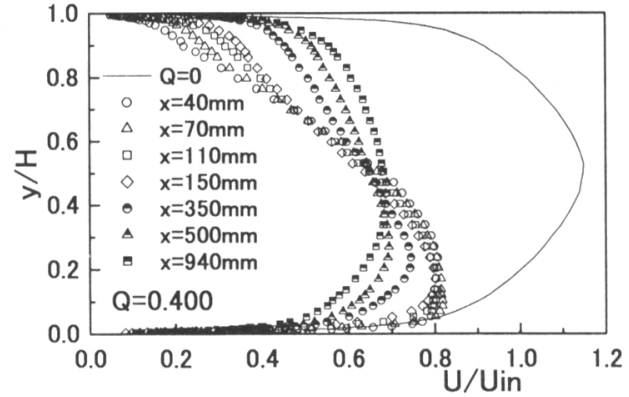

Fig. 12 Velocity profiles $\left(U / U_{\text {in }}\right)$

のみ大きく,スリットから離れた領域では急激に小さ くなる。

図 11 に示したように $x=20 \mathrm{~mm}$ より下流では垂直 方向速度成分は非常に小さくなることから，これょり 下流位置での速度分布, 乱流強度分布の測定には壁面 近傍の流動状況も詳細に観察するために I 形熱線プロ ーブを用いることとした. 図 12 はスリット下流 $(x=$ 40～940 mm）における速度分布の流れ方向への変化 を $Q=0.400$ を代表例として示している. なお，図 12 中の実線は $N u$ 数の測定と同様にスリットをテープ でふさぎ吸込みを行っていない場合 $(Q=0)$ における 速度分布である。吸込みによって流量が減少するため 流路内の流れは減速することになるが，この減速は上 壁面側に近い位置でより顕著となる。流路下側では $y / H=0.1$ 付近にピークをもつような分布となる.こ 


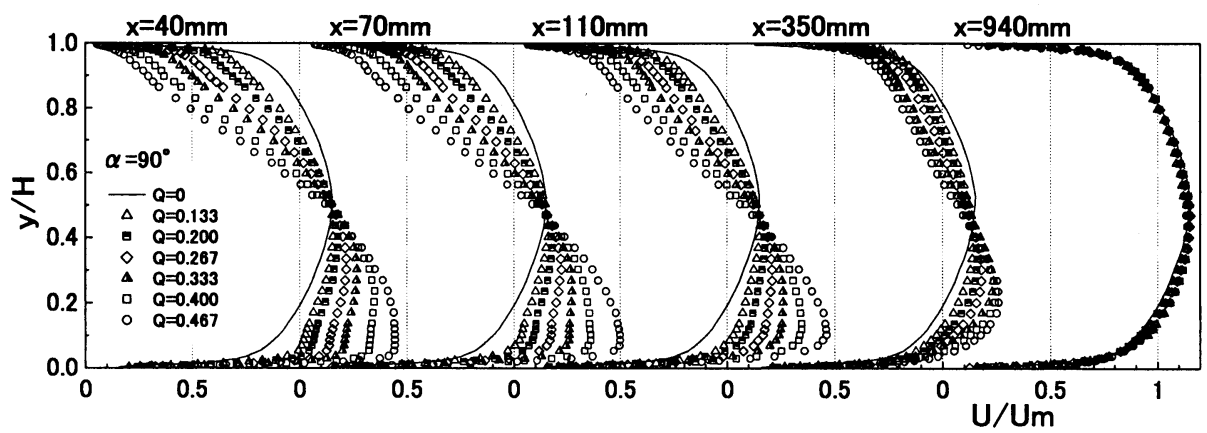

Fig. 13 Velocity profiles $\left(U / U_{m}\right)$

のピークは $x=150 \mathrm{~mm}$ の位置まで持続し, その值も あまり変化しない. 流れが下流に進むにつれて流路上 側の増速に対応して流路下側ではしだいに減速してい $<$.

図 13 にスリット下流における相対的な速度変化を 観察するために，Uをそれぞれの $Q$ におけるスリッ 卜下流の断面平均速度 $U_{m}$ で無次元化して比較した結 果を示す.スリット近傍において, 流路上側では $Q$ の増加に伴い速度の低下が見られ, 速度分布は直線的 な形状へと変化していく. 一方, 流路下側では $Q$ が 増加するほど局所的に増速してスリットに近い領域で は $y / H=0.1$ 付近に最大值が現れる. また, その最大 值が現れる付近の速度こう配は非常に小さくなってい る.いずれの $Q$ においても流路上側と下側とで非対 称となった速度分布は下流方向への回復が遅く, $x=$ $940 \mathrm{~mm}$ の位置においてもわずかではあるが吸込みに よる影響が残り，非対称性が認められる。

$3 \cdot 2 \cdot 5$ 乱流強度分布 図 14 にスリット下流にお ける流れ方向速度変動成分の $\mathrm{rms}$ 值 $u_{\mathrm{rms}}$ を $Q=$ 0.400 の場合を代表例として示す.なお， $u_{\mathrm{rms}}$ は $U_{\mathrm{in}}$ で無次元化がなされている.また, 図 14 中の実線は 速度分布の場合と同様に吸込みを行っていない場合に おける乱流強度分布である. 図 12 に示した速度分布 においてスリット近傍の $y / H=0.1 \sim 0.2$ 付近に見ら れた速度こう配の減少に対応して, 同様の位置で $u_{\mathrm{rms}} / U_{\mathrm{in}}$ の值が非常に小さくなっていることが確認で きる. 流れが下流に進むにつれて, しだいに流路上側 と下側の分布は対称なものへと回復してゆくが, $y / H$ $=0.1$ 付近に現れた極小值は速度分布の結果と同様に $x=150 \mathrm{~mm}$ まで下流方向にあまり変化しない. 壁面 近傍に注目すると, スリット直後の上壁面側では乱流 強度が減少し, 通常の管内乱流において認められる壁 面近傍でのピークが消失する. 一方, 下壁面側では明 りょうなピークが観察され， $x=150 \mathrm{~mm}$ の位置にお

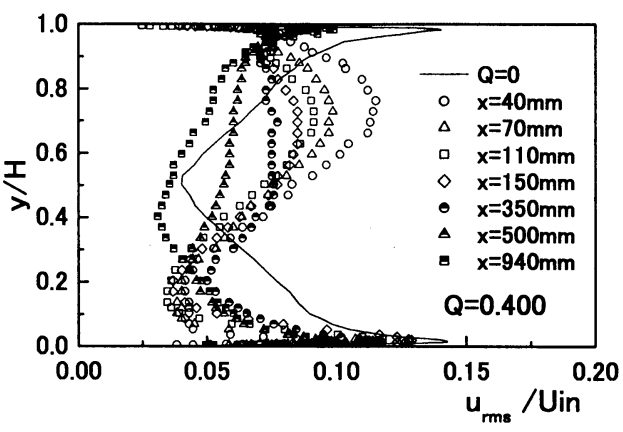

Fig. 14 Turbulence intensity $\left(u_{\mathrm{rms}} / U_{\mathrm{in}}\right)$

いては $Q=0$ において得られた乱れの $90 \%$ 程度の值 となる。

図 15 には $u_{\mathrm{rms}}$ を $U_{m}$ で整理した結果を示した。吸 込みにより, $y / H=0.7 \sim 0.8$ 付近の $u_{\mathrm{rms}} / U_{m}$ は $Q=0$ に比べて著しく増加し，かつ $Q$ が大きいほどその範 囲も拡大する. 断面平均速度に対する乱流強度の割合 は，吸込みにより増加することがわかる，また，この 大きな乱れの流れ方向への減衰は遅く, $x=350 \mathrm{~mm}$ の位置においても比較的大きな值を保持している．流 路下側においては, $x=40 \mathrm{~mm}, y / H=0.1$ 付近に現れ る乱れの小さな領域では，すべての $Q$ においてその 値がほぼ同程度となっている。また, 壁面近傍に見ら れるピーク值は $Q=0$ の結果に比較して大きな值を示 している.

図 16 にはスリット下流での流路下側および流路上 側の壁面近傍における乱流強度のピーク值 $u_{\mathrm{rms} p}$ の流 れ方向変化を $Q=0.200,0.400$ を代表例として示す. いずれの $Q$ においても下壁面側では流れの下流方向 にピーク值が増加し, 特に $Q=0.400$ の場合には 0.2 を超えるような大きな值となる。また, 壁面近傍で乱 れの大きくなる位置は, $N u$ 数分布において吸込みに よる熱伝達率の減少が緩和された領域とほほ一致して いることから, スリット下流の壁面近傍における乱れ 


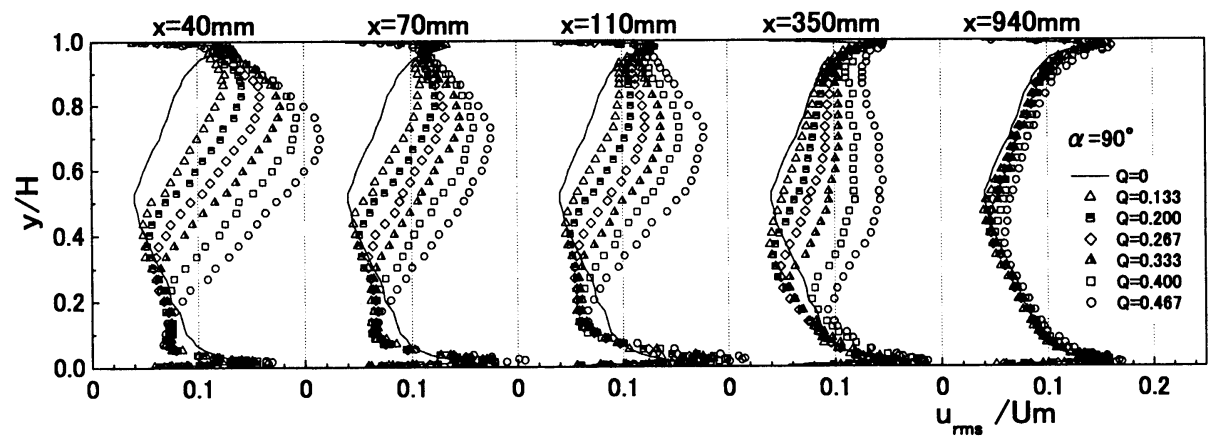

Fig. 15 Turbulence intensity $\left(u_{\mathrm{rms}} / U_{m}\right)$

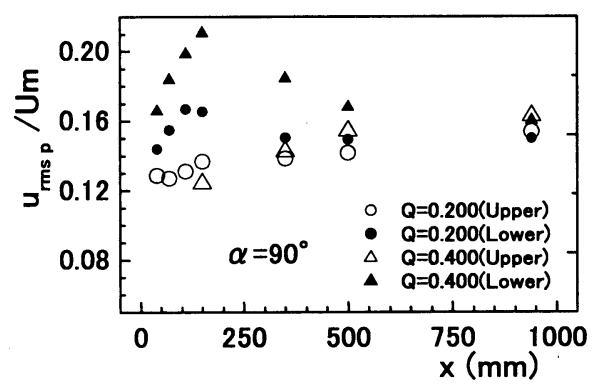

Fig. 16 Peak values of turbulence intensity near the wall

の局所的な増加がこの領域の熱伝達率の低下を抑制し ていると考えられる。一方, 上壁面側での乱流強度の ピーク值は単調な増加を示しており, 乱れの回復機構 が, 流路の下側と上側とで大きく異なっていることが わかる. なお, 浅井ら ${ }^{(11)}$ は, 乱流境界層に対して吸込 みを行うと壁面近傍に存在していた低速ストリークや 縦渦が消滅し，それに対応して乱れのピークも低下す るが, 流れが吸込み領域を通過した後には乱れのピー クも速やかに回復を開始すると報告している．本実験 結果の下側壁面近傍における乱れの変化のようすは， 浅井らの実験結果の傾向と一致している.

\section{4. 結 論}

本研究により得られた主要な結論を以下に示す.

（1）吸込み角度の相違が熱伝達率ならびに壁面静 圧分布に与える影響は非常に小さい.

（2）局所ヌッセルト数は吸込み流量比の増加とと もに減少する.しかし，スリット後方に局所ヌッセル 卜数の減少が緩和される領域が現れる。この領域は壁 面せん断応力ならびに壁面近傍の乱流強度が大きくな る位置とほほ一致している。

（3）吸込みによる垂直方向速度成分の変化はスリ
ット近傍でのみ大きく，スリットから離れた領域では 急激に小さくなる.

（4）スリット近傍においては，吸込み流量比の増 大に伴い流路上側での減速が大きくなる.一方, 流路 下側では $y / H=0.1$ 付近に極大值が現れ，流路上側と 下側とで非対称な速度分布となる．この非対称となっ た速度分布は下流方向への回復が遅い.

（5）断面平均速度に対する乱流強度の割合は，吸 込みにより増加する。乱れの回復機構は上壁面側と下 壁面側とで大きく異なる。

\section{文献}

(1) Antonia, R. A. et al., Physics of Fluids, Vol. 7 (1995), pp. 2465-2474.

(2) Antonia, R. A. and Fulachier, L., Journal of the Fluid Mechanics, Vol. 198 (1989), pp. 429-451.

(3) Sano, M. and Hirayama, N., Transactions of the Japan Society of Mechanical Engineers, Series B, Vol. 50, No. 450 (1984), pp. 520-529.

(4) Sano, M. and Hirayama, N., Transactions of the Japan Society of Mechanical Engineers, Series B, Vol. 50, No. 457 (1984), pp. 2041-2049.

(5) Oyewola, O. et al., Experiments in Fluids, Vol. 37 (2004), pp. 187-193.

(6) Komori, K. and Inagaki, T., Kagaku Kogaku Ronbunshu (in Japanese), Vol. 16, No. 2 (1990), pp. 275-279.

(7) Sofialidis, D. and Prinos, P., Transaction of the ASME, Journal of Fluid Engineering, Vol. 118 (1996), pp. 3339.

(8) The Japan Society of Mechanical Engineers ed., JSME Date book: Hydraulic Losses in Pipe and Ducts, (1979), pp. 86-95, The Japan Society of Mechanical Engineers.

(9) Nagata, N. et al., Proceeding 3rd ASME/JSME Fluids Engineering Conference, FEDSM 99-7356 (1999), pp. 1-8.

(10) Vogel, J. V. and Eaton, J. K., Transaction of the ASME, Journal of Heat Transfer, Vol. 107 (1985), pp. 922-929.

(11) Ashai, M. et al., Transactions of the Japan Society of Mechanical Engineers, Series B, Vol.68, No. 668 (2002), pp. 1016-1021. 